\title{
17
}

\section{Breaking the Liberal-Market Mold? Family Policy Variation Across U.S. States and Why It Matters}

\section{Cassandra Engeman}

In cross-national comparative studies, the United States is understood as the ideal-typical liberal regime that leaves work-life reconciliation for individuals and markets to address (Gornick \& Meyers, 2008; Korpi, Ferrarini, \& Englund, 2013). Fitting the liberal-market characterization, the United States lags behind most other countries in the world with respect to maternity and parental leave provisions (Heymann, Earle, \& Hayes, 2007). The Family and Medical Leave Act (FMLA), the only federal leave law in the United States, provides up to 12 weeks of job-protected leave for self-care or care of a parent, spouse, or child to address a serious illness or health condition. Leave provisions are unpaid, meaning that leave-eligible employees are guaranteed a return to the same position or a similar position with the same employer but do not receive wage-replacement benefits while on leave. Additionally, the FMLA's eligibility requirements effectively exclude workers employed part-time, in new jobs, or in small firms. ${ }^{1}$ According to a 2012

\footnotetext{
${ }^{1}$ Eligibility for leave under the FMLA requires employees to work at least 1250 hours in the year prior to taking leave from an (or each) employer. The employer must have 50 or more employees within a 75 -mile radius.
}

\section{Engeman $(\bowtie)$}

Swedish Institute for Social Research (SOFI), Stockholm University, Stockholm, Sweden

e-mail: cassandra.engeman@sofi.su.se 
study commissioned by the U.S. Department of Labor, the FMLA's eligibility requirements restrict over $40 \%$ of the workforce from the law's coverage (Klerman, Daley, \& Pozniak, 2014). Additionally, a majority of leave-eligible workers who report not taking leave when needed cite an inability to afford unpaid leave from work (Klerman et al., 2014; Waldfogel, 2001). The lack of paid, job-protected leave is most prevalent among women, low-wage workers, and workers of color (Milkman \& Appelbaum, 2013).

However, there is considerable subnational variation in U.S. family policy that cross-national comparative research often overlooks. The FMLA applies across states and provides base-level rights upon which state and local (municipal/county) laws can expand. Given the FMLA's limited coverage and benefits, subnational governments can expand leave rights and provisions in several ways. For example, provisions under state law can include wagereplacement benefits or lower or no eligibility requirements. As of 2017, twenty-five states offered more accessible leave provisions for private and public sector employees than provided under the FMLA (Engeman, 2018). While regularly issued policy reports describe the current status of family policy across U.S. states (see Engeman, Petts, Gatenio Gabel, \& Kaufman, 2019; National Partnership for Women and Families, 2016a, 2017a, 2018), less is known about the historical development of state leave laws.

This chapter examines state-level policy variation in the United States and addresses two main sets of questions concerning, first, policy variation across states and then, changes over time. First, what are the different types of statelevel leave provisions and how active have states been on leave policy? Second, how have state-level leave provisions developed over time? What are the main landmarks and trends? ${ }^{2}$ My policy research draws from multiple primary sources, including state legislative documents, and secondary sources, such as academic publications on policy developments prior to the FMLA. Using these sources, I identify 72 leave laws adopted by U.S. states between 1942 and 2017. To discuss my state-level findings, I compare state leave legislation with leave policy development across affluent democratic countries. ${ }^{3}$ With this comparison, I highlight some often-overlooked, innovative aspects of U.S. family policy and argue that state-level leave policies developed along a distinct trajectory.

\footnotetext{
${ }^{2}$ Anne Gauthier's (2004 [1996]) seminal work explores the same question for family policy development across affluent countries.

${ }^{3}$ By affluent democratic countries, I am referring to a common set of countries in cross-national comparative policy analysis, namely: Australia, Austria, Belgium, Canada, Denmark, Finland, France, Germany, Greece, Ireland, Italy, Japan, Luxembourg, Netherlands, New Zealand, Norway, Portugal, Spain, Sweden, Switzerland, the United Kingdom, and the United States.
} 
Social policies providing time-off from work to address medical needs and to care for new children or other family members have wide-ranging benefits-from improved public health (see Rossin, 2011; Ruhm, 2000; Widera, Chang, \& Chen, 2010) to workforce stability (see Pavalko \& Henderson, 2006; Rosenfeld, 2007) and family economic security (see Gould, Filion, \& Green, 2011; Rossin-Slater, Ruhm, \& Waldfogel, 2013). Studies in other country contexts show that leave policies, together with public childcare, help reconcile work and family obligations (Cukrowska-Torzewska, 2017; Ruppanner, 2013), reduce poverty (Maldonado \& Nieuwenhuis, 2015), and influence women's labor force attachment (Korpi et al., 2013; Rønsen \& Sundström, 2002) and lifetime earnings (Cukrowska-Torzewska, 2017). Yet, establishing parental and family leave provisions in the United States has been a decades-long project that continues to challenge leave-policy advocates. While Democrats have introduced paid family leave legislation in Congress four times since $2013,{ }^{4}$ these proposals have yet to move from the early stages of the policy-making process. ${ }^{5}$ Given the lack of political will at the federal level and the societal importance of medical and caregiving leave, this chapter emphasizes the importance of understanding state-level policy developments and promising reforms.

The chapter proceeds as follows. The following section describes the development of the FMLA and highlights the compromises made in the policy process that left room for subsequent state-level expansions. After a brief description of methods, I identify different types of leave policies and show how a select few states are more active than others. The more active states have more generous provisions, suggesting efficacy for incremental approaches to policy change in some states. Then, I describe state policy development over time and show how leave provisions targeting female employees was abandoned early in favor of gender-neutral individual entitlements. I argue that state-level leave provisions can be distinguished by whether they address gender-neutral health or family caregiving needs. The emphasis on gender-neutral individual entitlements in U.S. leave policy, I argue, creates an opportunity for leave advocates to layer wage-replacement benefits on top of job-protected leave in a step toward gender-egalitarian family policy models found in other countries. I conclude by arguing that subnational variation

\footnotetext{
${ }^{4}$ Legislation was introduced as the Family and Medical Insurance Leave Act in the 113th and 114th Congress and the FAMILY Act in the 115th and 116th Congress.

${ }^{5}$ Specifically, the bills have been stuck in committee. Any one lawmaker can introduce legislation, making bill introduction a relatively easy achievement for policy advocates. Once a bill is introduced, however, it is referred to one or more committees, and committee chairs, who are appointed by the majority party, decide what bills receive hearings and are brought for a vote in committee. Committees must approve bills before they are sent back to the house (or legislative body) for a vote.
} 
in social policy is a rich area for future research and cross-national comparative analysis of family policy outcomes should consider subnational variation when including federal systems.

\section{The FMLA: Setting an Incremental Agenda for Leave Rights in the States}

Although provisions under the FMLA are limited compared to leave provisions in other countries, the FMLA was contentious legislation. A version was introduced in five congressional sessions starting in 1985 and vetoed twice before becoming law in 1993 (Elving, 1995). In the course of negotiating the FMLA, several compromises set the stage for state policy development. First, providing wage-replacement benefits was rejected as a policy idea before legislation was introduced (ibid.). Leave advocates knew that without wage-replacement benefits, access to leave rights would be limited to higherearning professionals who likely already had employer-provided paid leave, and unpaid leave provisions would do little to improve the lives of lowincome workers who needed leave rights most (Bernstein, 2001, pp. 44-45, 96). Yet, while drafting the original bill, lawmakers and a small group of feminist attorneys, union representatives, and other leave advocates agreed to pursue unpaid rather than paid leave (Elving, 1995). The decision to pursue unpaid benefits was based on a consideration of the bill's potential financial impact should benefits be provided (Sholar, 2016) and the partisanship of the executive and legislative branches (Elving, 1995). With a Republican president and a Republican majority in the Senate, proponents thought a paid leave bill would lack credibility (ibid.). Though an increasing number of states are adopting paid leave programs, establishing wage-replacement benefits remains a major hurdle for expanding leave rights.

Second, leave advocates rejected maternity leave early in the policy process in favor of gender-neutral family caregiving leave (Elving, 1995, p. 39). The question of whether to pursue maternity leave or gender-neutral (parental or family) leave conjured debates about whether women needed different or equal treatment and whether equal treatment-specifically, an equal lack of leave rights-resulted in equality (see Shiu \& Wildman, 2009). Maternity leave would be easier to pass compared to gender-neutral parental or family leave, because it would be narrower in coverage and have broader appeal as a protective measure for vulnerable mothers (Bernstein, 2001). However, some leave advocates worried that leave rights tied to pregnancy and childbirth 
would further incentivize discrimination against women (Elving, 1995). Ultimately, advocates decided to emphasize equality over protection and opposed proposals to limit leave rights to women (Bernstein, 2001, pp. 44-45; Elving, 1995, p. 39). Instead, leave proponents broadened the original bill, which proposed parental leave, to include leave to care for spouses, parents, and older children (Elving, 1995, p. 66). ${ }^{6}$ As I will show in the following sections, inclusive family leave and gender-neutral individual entitlements became the normative form of state-level leave provisions after the FMLA.

Third, proponents agreed to limit the possible uses of leave and add eligibility requirements in an effort to gain Republican support (Elving, 1995). Early in the policy process, proponents agreed to interpret the bill's leave provisions to exclude leave for "non-recurring conditions for which treatment and recovery last no more than a few days" (ibid., p. 57). By excluding shortterm health needs, proponents sidestepped the contentious issue of granting leave for abortions, which would have drawn active opposition, potentially ruining the bill's chances of passing (ibid.). As a result, however, under federal law, American workers lack rights to paid sick leave to recover from minor illnesses. Paid sick leave, therefore, remains an issue that can be addressed under state policies.

Finally, eligibility requirements were introduced into the bill by a supportive Republican member of the House of Representatives. In an effort to gain additional support from fellow Republicans, Representative Margaret Roukema proposed shortening leave duration, adding "minimum service requirements" for leave eligibility, and limiting the law's coverage to establishments with 50 or more employees (Elving, 1995). Congress passed the bill with Roukema's amendments, but President George H.W. Bush vetoed it. Introducing the bill again, proponents agreed to increase the number of hours a worker would need to work before qualifying for leave-from 1000 hours to 1250 hours in the year prior to taking leave. President Bush vetoed the bill a second time, and proponents lacked the votes in the House to override the veto (ibid.). The 1992 elections resulted in Democrats winning the presidency and a majority of seats in both houses of Congress. Despite the new favorable political context, proponents decided to introduce a bill with the previously amended language to assure a swift victory (Bernstein, 2001; Elving, 1995). After sixteen days in office, President Bill Clinton signed the Family and Medical Leave Act (FMLA). Thus, the restrictive eligibility requirements remain, presenting a fourth way for states to expand leave rights.

\footnotetext{
${ }^{6}$ Including care for relatives broadened the bill's appeal and won active support from organized labor and the American Association of Retired People (AARP). Together, these organizations provided most of the funding for the coalition advocating leave legislation (Bernstein, 2001, p. 99).
} 
Leave advocates planned to return to family policy later to reform provisions incrementally (Elving, 1995). Despite such aspirations, family policy has been a project for the states. In the context of congressional inaction, both before and after the FMLA, states adopted their own leave laws. When a version of the FMLA was first introduced in 1985, it inspired state legislative action on leave issues (Bernstein, 2001, p. 122). In 1987, 28 states introduced family and medical leave bills (Wisensale \& Allison, 1989), and preceding the FMLA, eleven states adopted parental and family leave laws (see Engeman, 2018). All of these laws are still in effect, because they are more generous than the FMLA in at least one respect. While the FMLA applies across states, its limitations create opportunities for states to expand leave rights in several ways. Some states provide paid family leave (e.g., California, New Jersey, New York, Rhode Island, and Washington). Other states adopted unpaid, jobprotected leave laws that, compared to federal law, grant longer leave, cover smaller establishments, or include broader definitions of family for caregiving leave purposes. Given the institutional and political challenges of expanding social policy in the United States, the establishment of leave rights marks a notable accomplishment.

Few researchers have examined the historical development of state leave laws, particularly after the passage of the FMLA (for exceptions, see Engeman, 2016, 2018; Sholar, 2016; Williamson \& Carnes, 2013). In this chapter, I contribute to previous research by tracing policy developments across states and over time. I show how the FMLA and subsequent state policies established gender-neutral individual entitlements and inclusive family (as opposed to parental) leave as normative elements of leave policy.

\section{Methods}

For this chapter, I compiled and coded state leave laws covering both private and public sectors. To identify state leave laws and their enactment dates, I drew from multiple sources. Specifically, I used reports by the National Partnership for Women and Families (2015a, 2016a, 2017a, 2018), the National Conference of State Legislatures (2008), the Women's Bureau of the U.S. Department of Labor (1993, 2017), and a cross-institutional report by Workplace Flexibility 2010 at the Georgetown University Law Center and the Berkeley Center on Health, Economic \& Family Security at the UC Berkeley School of Law (2010). I also consulted legal and academic publications to track the development of state laws prior to the FMLA. Using the legal references cited in secondary reports and publications, I searched LexisNexis 
Congressional, an archive of state laws and statutes, to find original language and enactment dates. When legal documents were unclear, I searched local media reports and legislative archives on state government websites.

States also adopted other types of family policies that were not included in my analysis. For example, some states have adopted leave policies covering state employees only. I did not include these laws in my analysis, because they better reflect labor relations between a state and its workforce than social policy, which is my main interest. I also exclude small necessities leave laws. Small necessities leave is used to address occasional, short-term needs, such as attending a child's school activity, grieving a family member killed in active military duty, or addressing issues related to domestic violence, sexual assault, and/or stalking. The diversity of small necessities leave laws makes them difficult to track comprehensively. I therefore leave this task for future research.

Family policies that are not leave policies are excluded from my analysis. Previous policy reports describe employment protections for pregnant employees (U.S. Department of Labor, 2015) or assess state-level "family friendliness" that consider, for example, space at work to express milk (NPWF, 2016a, 2017b). My analysis also distinguishes between leave provisions and anti-discrimination laws protecting pregnant employees. Antidiscrimination laws do not grant leave. Rather, they require employers treat pregnant employees the same as they would treat other temporarily disabled employees. ${ }^{7}$ I also distinguish parental and family leave laws from flexible use laws that allow flexible use of employer-provided paid sick leave. For example, California passed a "Kin Care" law in 1999 requiring employers who provide sick leave to allow use of sick leave to care for a sick parent, spouse, or child. Like anti-discrimination laws, flexible use laws do not grant leave rights. Rather, they govern how employees can use employer-based provisions.

After compiling a comprehensive list of state leave laws meeting my aforementioned specifications, I coded the laws by enactment year, state, and type of leave policy and included a detailed description of provisions. Using this coding method, I determined how many laws each state adopted and examined policy development over time (for a timeline of state leave legislation and comprehensive documentation of sources, see Engeman, 2018).

\footnotetext{
${ }^{7} \mathrm{~A}$ temporary disability is a non-work-related injury or illness that prevents work for a short period of time while the employee recovers.
} 
Table 17.1 Types of state leave laws in 2017

\begin{tabular}{ll}
\hline Type of leave & Description \\
\hline Pregnancy disability and childbirth & $\begin{array}{c}\text { To address medical issues related to } \\
\text { pregnancy and childbirth } \\
\text { To care for/bond with a new child, may } \\
\text { also include welcoming a newly } \\
\text { adopted or newly placed foster child } \\
\text { To care for a seriously ill family member, } \\
\text { most commonly a parent, spouse, or } \\
\text { child } \\
\text { To care for a seriously ill family member } \\
\text { or for self-care to address serious } \\
\text { illness or health condition } \\
\text { To address a short-term illness while } \\
\text { receiving wage replacement (100\%) } \\
\text { from employer } \\
\text { To receive wage replacement benefits } \\
\text { during leave to address a serious } \\
\text { illness, non-work-related injury, or } \\
\text { health condition (including but not } \\
\text { limited to pregnancy and childbirth). } \\
\text { Some temporary disability insurance } \\
\text { programs provide wage replacement } \\
\text { but not job-protection }\end{array}$ \\
To receive wage replacement benefits \\
during leave to care for a seriously ill \\
family member. Some paid family leave \\
insurance programs provide wage \\
replacement but not job protection
\end{tabular}

\section{Family Policy Reforms Across States: Policy Types and Legislative Activity}

Between 1942 and 2017, U.S. states adopted 72 leave laws. ${ }^{8}$ Most laws established or expanded unpaid, job-protected leave. I categorize provisions into seven types based on the purpose of the leave and whether wage-replacement benefits are provided (see Table 17.1). Of the unpaid provisions, types of leave include pregnancy and childbirth, parental, family, and family and medical leave. ${ }^{9}$ Short-term paid sick leave is provided by employers at $100 \%$ of earnings. To provide wage-replacement benefits during longer durations of leave,

\footnotetext{
${ }^{8}$ The leave laws counted here meet the criteria described under the methods section.

${ }^{9}$ Small necessities leave is an additional type of leave provision that is common across states. However, these laws are excluded from the table, because they are excluded from my analysis (see justification under methods section).
} 
states have adopted temporary disability insurance and paid family leave insurance programs.

As of 2017, six states-California, Hawaii, New Jersey, New York, Rhode Island, and Washington-have temporary disability insurance or paid family leave insurance or both. ${ }^{10}$ As insurance programs, some do not provide job protection. ${ }^{11}$ Rather, when an employee needs to take time-off from work to care for family or address a non-work-related injury, illness, or disability, including pregnancy- and childbirth-related disabilities or health issues, the employee can file a claim for benefits under the state insurance program. Rights to return to the same or similar position with the employer, when not provided under the insurance program, are covered under state and federal laws, though eligibility requirements may limit access. Employee payroll contributions fund most insurance programs, though employers and employees jointly fund the temporary disability programs in Hawaii, New Jersey, and New York and paid family leave insurance in Washington. Wage-replacement benefits across all programs are granted as individual entitlements. All paid family leave insurance programs pay benefits during leave to care for a parent, spouse, domestic partner, or child, but many laws cover care for additional family members. Benefits are paid between six and twelve weeks at between 50 and $90 \%$ of previous earnings to a cap, and New York's and Washington's benefit levels are calculated based on the state's average weekly wage.

Few states have approached family policy as an incremental project. Six states-California, Hawaii, Massachusetts, New Jersey, Rhode Island, and Washington-are responsible for adopting over half of the 72 leave laws enacted between 1942 and 2017. Figure 17.1 illustrates the unevenness in legislative activity across states. As shown in the figure, private sector employees in half of the states are covered only under the FMLA. ${ }^{12}$

Eleven states have passed only one law. Nine of these eleven states passed their one law within the five years that Congress debated the FMLA. These nine states-Illinois, Iowa, Kansas, Kentucky, Louisiana, Montana, New Hampshire, Ohio, and Wisconsin-passed laws prior to 1993 and have been inactive since. Arizona and Maryland each passed one law after the FMLA.

\footnotetext{
${ }^{10}$ Massachusetts adopted a paid family leave insurance program in 2018 that will begin paying benefits in 2021.

${ }^{11}$ Paid leave insurance programs in New York, Rhode Island, and Washington also provide job protection.

${ }^{12}$ Some state employees may be covered under other state leave laws. Of course, private sector employees may also have employer-provided leave rights, either voluntarily from employers or under collective bargaining agreements.
} 


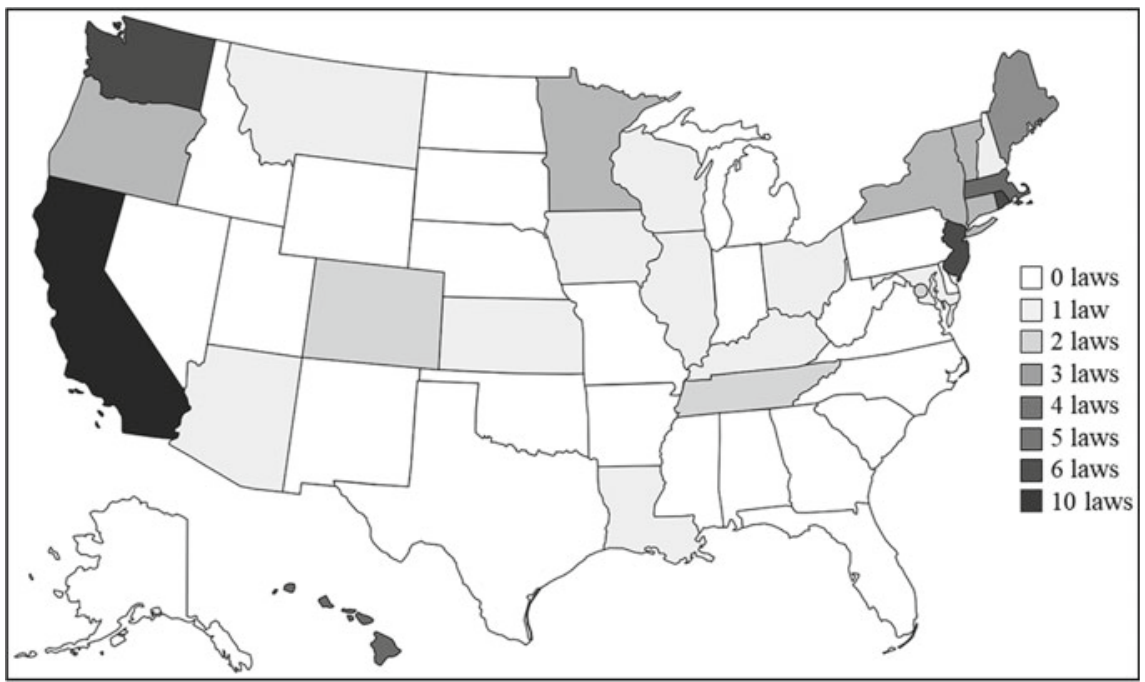

Fig. 17.1 Level of legislative activity in the states: number of leave laws enacted, 1942-2017

Arizona adopted paid sick leave law with a ballot measure in 2016, and Maryland passed parental leave legislation in 2014 to cover smaller establishments than covered under the FMLA. Eight of the nine pre-FMLA laws in one-law states grant leave only to female employees. ${ }^{13}$ In these states, family policy is thus stuck in a female-targeted, pre-FMLA policy framework.

The more active states generally have more generous provisions (see Fig. 17.2). Fourteen states have passed more than one law, and each of these states passed laws both before and after the FMLA. These states include: California, Colorado, Connecticut, Hawaii, Maine, Massachusetts, Minnesota, New Jersey, New York, Oregon, Rhode Island, Tennessee, Vermont, and Washington. After the FMLA, these incremental states passed additional laws, expanding FMLA provisions or coverage in some way. Five states-California, New Jersey, New York, Rhode Island, and Washington-adopted paid family leave insurance by 2017 . Other laws expanded leave rights in smaller ways. For example, five states-California, Hawaii, Maine, Oregon, and Rhode Island-expanded job-protected family leave to cover care for additional family members and "reciprocal beneficiaries." In contrast, Tennessee and Colorado passed two laws each and expanded FMLA provisions in only small ways. Tennessee provides an extra month of leave with respect to the FMLA but covers establishments of 100 or more employees. Colorado's

\footnotetext{
${ }^{13}$ The exception is Wisconsin, which adopted family and medical leave in 1987.
} 


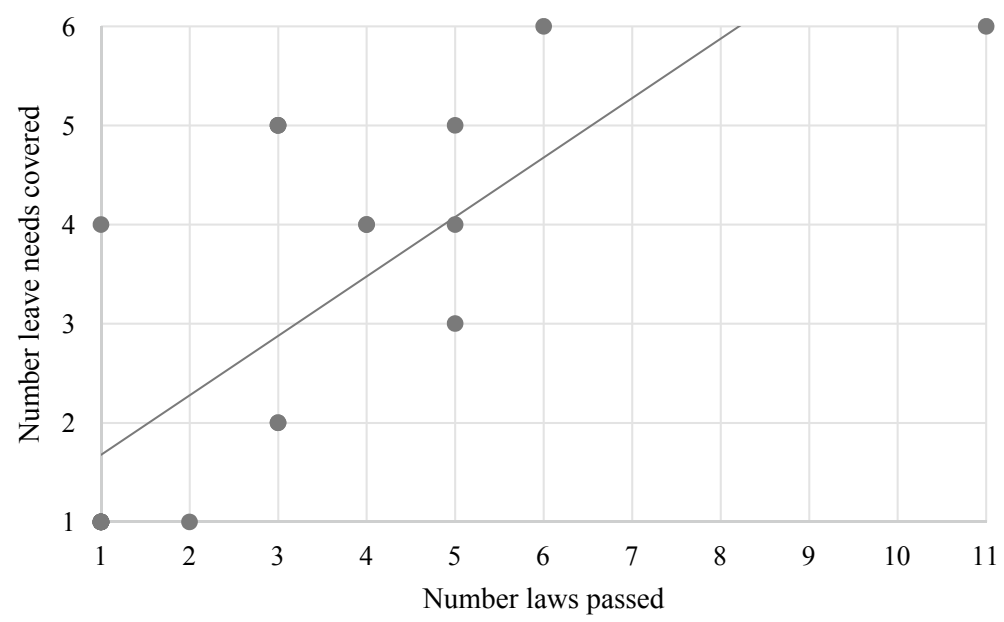

Fig. 17.2 The number of laws passed by the number of leave needs covered (Note Combining temporary disability and family leave insurance, this figure includes six categories of leave needs: pregnancy and childbirth, parental, family, [other] medical, paid sick leave, and longer-term paid leave insurance)

law broadens "family" for the purpose of family caregiving leave to include domestic or civil union partners. Although a select few states have achieved more generous provisions with fewer laws, ${ }^{14}$ most incremental states improve leave access and affordability by adopting multiple, minor reforms.

\section{Family Policy Reforms Over Time: Historical Landmarks and Trends}

In this section, I identify five cross-state trends in leave policy development and discuss them in the context of important landmarks. I argue that in the process of state-level policy development, leave advocates and lawmakers abandoned policies that restrict bonding/caregiving leave to mothers in favor of gender-neutral, individual entitlements to address either medical or family caregiving needs.

\footnotetext{
${ }^{14}$ For example, New York adopted three leave laws compared to California’s eleven, but New York's paid family leave insurance is more generous than California's, offering job protection and longer leave duration (although fourteen years after California).
} 


\section{Temporary Disability Insurance, 1942-1969}

From 1942 to 1969, five states-California, Hawaii, New Jersey, New York, and Rhode Island-adopted temporary disability insurance (TDI) programs. TDI programs ${ }^{15}$ offer wage-replacement benefits during leave from work to address illness or non-work-related injury. ${ }^{16}$ TDI programs originally excluded pregnancy and childbirth as qualifying disabilities for benefit claims. These programs are still in effect but now include pregnancy and childbirth as qualifying disabilities, as will be discussed below. As insurance programs, employees can apply for benefits when they miss work, but job protection or the guaranteed return to the same or similar position with the same employer were not included. Instead, job protection was provided by employers on a voluntary basis or under collective bargaining agreements or later, under state and federal laws. Employee payroll contributions fund TDI programs in California and Rhode Island, and employers and employees jointly fund TDI programs in Hawaii, New Jersey, and New York (for a comprehensive summary of state TDI programs, see Workplace Flexibility, 2010, pp. 109111). Because the early TDI programs did not cover leave for pregnancy or childbirth, they were not technically family policy. However, these programs laid the foundation for paid disability leave for pregnancy/childbirth and paid family leave insurance programs.

\section{Pregnancy Disability Leave, 1961-1985}

Starting in the 1960s, state lawmakers began to consider the rights of pregnant employees. The first leave-related family policies were established by reforms to TDI programs. In 1961, New Jersey added pregnancy and childbirth as qualifying disabilities for receiving TDI benefits. Hawaii (in 1973), California (in 1976), and New York (in 1977) followed with the same reform. Finally, as a result of the Pregnancy Discrimination Act in 1978, Rhode Island's TDI program covered leave for pregnancy- and childbirth-related health issues. The expansion of TDI programs did not create new rights to job-protected leave but allowed female employees who had contributed to state insurance programs to draw benefits for pregnancy- and childbirthrelated disabilities. Thus, the inclusion of pregnancy- and childbirth-related disabilities under TDI programs was consistent with anti-discrimination

\footnotetext{
${ }^{15} \mathrm{TDI}$ is referred to as state disability insurance (SDI) in California.

${ }^{16}$ Workers' compensation laws cover work-related injuries.
} 
measures, because it resulted in equal treatment of temporarily disabled employees regardless of sex.

Lawmakers, feminists, and legal professionals debated whether equal provisions under the law resulted in gender-equal outcomes. At issue was whether job-protected leave for pregnant employees would further incentivize employer discrimination against women and whether the absence of job-protected leave for pregnant employees was discriminatory, resulting in unequal employment outcomes for men and women (Elving, 1995; Shiu \& Wildman, 2009). The Civil Rights Act of 1964 made discrimination on the basis of race, color, religion, sex, or national origin unlawful. The inclusion of "sex" as a protected category left ambiguous whether disciplinary actions against pregnant employees were unlawful (Elving, 1995). In 1976, the Supreme Court ruled that discipline or dismissal of a pregnant employee did not violate the Civil Rights Act (Shiu \& Wildman, 2009). In response, Congress passed the Pregnancy Discrimination Act of 1978, prohibiting discrimination based on pregnancy. Under this law, employers were required to treat pregnant employees the same as other temporarily disabled employees. Therefore, any employer-provided paid or unpaid, jobprotected leave for disabled employees must also be extended to pregnant employees. Alternatively, an employer could discipline or dismiss a pregnant employee for needing accommodation or time-off if the employer would take the same action against an employee with another type of temporary disability (ibid.).

In the midst of debates over "equal treatment" (e.g., anti-discrimination) versus "special treatment" (e.g., maternity leave rights), states began adopting unpaid, job-protected leave to address medical issues related to pregnancy and childbirth. Between 1972 and 1985, ten states adopted such laws. ${ }^{17}$ Many of these early laws were unclear about duration and had low or no eligibility requirements. California's pregnancy disability leave policy provided four months of job-protected leave, and Massachusetts' maternity leave policy provided eight weeks. However, in the remaining eight states, leave duration was unspecified or stipulated as a "reasonable" period of time. Leave provisions in four states had no eligibility requirements, and the other state laws covered comparatively small establishments, starting at employers with 3-8

\footnotetext{
${ }^{17}$ California's and Montana's pregnancy disability leave laws, enacted in 1978 and 1975, respectively, were later challenged in court for potential violation of the Pregnancy Discrimination Act (Shiu \& Wildman, 2009). Both state laws were upheld in court (ibid.), leaving the possibility to adopt job-protected leave rights for pregnancy and childbirth open to other states.
} 
or more employees. Only Massachusetts' provision had a tenure-based eligibility requirement; to be eligible for job-protected maternity leave, employees needed to work at least three months for the employer.

Until 1985, state policies established job-protected leave only for pregnancy and/or childbirth, and these rights were restricted to addressing medical issues. Only two states offered exceptions during this period by providing leave to bond with new children. The Massachusetts Maternity Leave Act of 1972 provided eight weeks of unpaid maternity leave for nursing and to address health issues related to pregnancy and childbirth. Massachusetts then extended the law in 1984 to cover time-off to bond with newly adopted children but restricted this provision to women. Kentucky, in 1982, became the first state to adopt a gender-neutral leave policy, but rights were restricted to the purpose of bonding with a newly adopted child.

\section{Gender-Neutral, Job-Protected Leave, 1985-1993}

In 1985, the first bill to propose job-protected caregiving leave was introduced in Congress. The Parental and Disability Leave Act, which eventually became the FMLA, proposed 18 weeks of parental leave and 26 weeks of disability leave and leave to care for sick children (Elving, 1995). Provisions were gender-neutral, unpaid, job-protected, and granted as individual entitlements. With the introduction of this bill, proponents found a way to bypass the equal treatment-versus-special treatment debate by creating leave rights without reference to sex or gender (ibid.).

States responded to policy developments in Congress with their own versions of gender-neutral leave. By 1993, two states provided job-protected parental leave to care for a newborn, newly adopted, or newly placed foster child. Two states provided family leave to care for a new child and a parent, spouse, or child with a serious illness or medical condition. Seven states provided family and medical leave to care for a family member or a new child or for employees to address their own serious illness or medical condition, including pregnancy- and childbirth-related health issues. Three of the four states that adopted parental or family leave policy but not medical leave had previously passed pregnancy disability leave laws; therefore, leave for pregnancy-and childbirth-related health issues were already covered. For the gender-neutral leave policies adopted in this period, provisions ranged in duration from six to twelve weeks.

As congressional lawmakers finalized the FMLA, state policies converged around leave provisions for an inclusive range of care needs. Policies adopted 
closer to 1993 were more likely to provide leave for temporary disabilities, infant/child care, and family care (i.e., family and medical leave). For example, Oregon and Rhode Island-early adopters of gender-neutral leave provisions-adopted parental leave first (both in 1987) and then expanded provisions (in 1989 and 1990, respectively) to include leave to care for non-child relatives - thus, establishing family leave.

Yet, some states in this period continued on the previous path of policy development by adopting leave provisions for pregnancy and childbirth only. Seven states-Illinois, Iowa, Louisiana, Tennessee, Ohio, Oregon, and Vermont-adopted such policies. Of these states, Oregon and Vermont also adopted gender-neutral leave provisions by 1993. Lawmakers in Tennessee, however, were so adamant about restricting leave rights to female employees they reformed the state's maternity leave law one year later to clarify that the leave was not for gender-neutral "bonding" but for pregnancy, childbirth, and nursing-activities tied to female bodies (Bernstein, 2001, p. 73). Between 1985 and 1993, leave rights in Massachusetts also remained restricted to female employees. Massachusetts expanded its maternity leave policy to include care for disabled children but did not extend leave rights to fathers, even as other states passed gender-neutral laws. In her case study of Massachusetts, Anya Bernstein (2001) shows how leave advocates were determined to establish wage-replacement benefits for family leave but failed. Unwilling to compromise on wage-replacement benefits, leave advocates also failed to adopt any unpaid, gender-neutral leave policy. Bernstein (2001) argues that in other states, like Iowa, Louisiana, and Tennessee, leave advocates adapted their policy goals to their respective state political contexts and won job-protected leave for mothers.

\section{Implementation and Assessment, 1993-1998}

After the FMLA passed, the adoption of new state leave legislation slowed. During this time, states adopted only three leave policies. Oregon consolidated provisions from its separate pregnancy disability, parental, and family and medical leave policies. Hawaii broadened its definition of "family" for family caregiving purposes to include reciprocal beneficiaries, and Maine began covering smaller employers (i.e., with fifteen or more employees) under its family and medical leave policy. 


\section{Paid Leave and Other Expansions, 1999-2017}

In 2002, California became the first state to adopt paid family leave insurance. The state's paid family leave program was created by expanding its disability insurance program to cover leave to care for family members, including bonding with new children. Preceding the adoption of paid family leave insurance, California lawmakers in 1999 increased the level of disability insurance benefits. The state legislature also commissioned a fiscal impact study on the estimated costs of using state disability insurance funds to pay benefits during family caregiving leave. The study, released in 2000, showed that an extension of the state disability insurance program was feasible (Firestein, O'Leary, \& Savitsky, 2011).

Following California's example, all of the states with TDI programsexcept Hawaii-extended their programs to cover family caregiving leave, including care for a newborn, newly adopted, or newly placed foster child. Specifically, these states included: New Jersey (in 2008), Rhode Island (in 2013), and New York (in 2016). Washington adopted a paid parental leave insurance program in 2007, just before the recession. Lacking a preexisting funding mechanism in the form of a TDI program, Washington's original program was never implemented. Ten years later and with new legislation, Washington became the first state without a TDI program to establish a paid family leave insurance program, with benefit payments starting in 2020 .

States also adopted paid sick leave legislation. The legislation allows employees to accrue leave-paid by employers at $100 \%$ of the employee's previous earnings - to recover from short-term illnesses, like the flu. The first government to adopt earned sick leave was the City of San Francisco in 2006 (NPWF, 2015b), and in 2011, Connecticut became the first state to adopt the policy. Six states followed: California (in 2014), Massachusetts (in 2014), Oregon (in 2015), Arizona (2016), Washington (in 2016), and Vermont (in 2016). The laws - three of which passed by ballot measure-allow employees to accrue hours of leave based on the numbers of hours worked, up to a cap of either 24 or 40 hours and, except for Connecticut's law, ${ }^{18}$ cover small establishments.

\footnotetext{
${ }^{18}$ As the first state to adopt paid sick leave legislation, the coverage of Connecticut's paid sick leave law is comparatively limited. The law only covers employees in establishments of 50 or more employees working in "public contact occupations," for example, food service or public health. Proponents of earned sick leave advocated for policy change in the midst of the H1N1 outbreak (Greenhouse, 2009) and in motivating the need for paid sick leave, emphasized the public health risks of lacking access to paid sick leave, particularly in the service sector. Connecticut is the only state to restrict access to paid sick leave in these ways.
} 
During this period, states also expanded unpaid, job-protected leave rights. Eleven laws amended leave rights by expanding leave duration, covering smaller establishments, allowing care for additional family members, or extending leave provisions in some other way. Most notably, Tennessee (in 2005) and Massachusetts (in 2015) extended leave rights to men under their existing state policies. The most frequent type of expansion was broadening the definition of family for the purpose of family caregiving leave. California in 2013 also broadened the definition of family for receiving benefits from the paid family leave insurance program. Under the program, eligible employees can now receive benefits while on leave to care for grandparents, grandchildren, siblings, and parents-in-law. Rhode Island, New York, and Washington-adopting paid family leave insurance programs after California's 2013 expansion-included a similar set of additional family members in their original laws.

\section{State-Level Leave Policy Development in Cross-National Comparative Perspective}

U.S. state-level leave provisions differ from provisions in other countries in several ways. First, one of the most apparent differences is the prevalence of unpaid leave. While the United States is decades behind most other countries in the world with regard to paid leave, particularly for mothers (Heymann, Earle, \& Hayes, 2007), the availability and need for job protection to address caregiving needs should not be minimized. Prior to the adoption of jobprotected leave laws in the 1980s, employers could terminate employees for missing work to give birth or missing work or needing accommodations for pregnancy-related health issues. With equal treatment under the law, employers could discipline or dismiss pregnant employees if they would take similar actions against other employees for work interruptions due to other temporary illnesses or injuries (Shiu \& Wildman, 2009). Thus, researchers have found that even unpaid family leave improves women's labor force attachment (Pavalko \& Henderson, 2006).

Second, unlike family policies in other countries, all leave rights and provisions in the United States are individual entitlements. In other countries, separate policies provide paid leave for mothers during pregnancy, for childbirth, and to care for a newborn (maternity leave), paid leave for fathers around the birth of the child (paternity leave), and paid leave for parents to care for a newborn (parental leave) (Koslowski, Blum, Dobrotić, Macht, $\&$ Moss, 2019). To strengthen women's employment and encourage fathers' 
involvement in caring for new children, governments began—in the 1990sto create individual parental leave entitlements or convert portions of shared leave provisions into individual entitlements for fathers/partners (Brandth \& Kvande, 2018; Daly, 2010; Daly \& Ferragina, 2018; Karu \& Tremblay, 2017). Whereas gender-neutral, individual entitlements are the norm for U.S. state-level leave laws, they are debated and under threat in other countries. Because individual parental leave entitlements incentivize fathers' leave-taking (Brandth \& Kvande, 2018; Duvander \& Johansson, 2012; Escot, FernádezCornejo, \& Poza, 2014; Haas \& Rostgaard, 2011, also see Chapter 15 by Bartova $\&$ Keizer in this volume) or, in some cases, reduce shared parental leave duration, debates about individual entitlements center on whether governments should play a role in how people divide labor within their families (Borchorst, 2006; Chronholm, 2009; Ellingsæter, 2012; Eydal et al., 2015). While individual entitlements are not debated in the United States, unpaid leave does little to promote gender egalitarianism as men are unlikely to take unpaid leave or leave paid at low levels (see Kaufman, 2018; Moss, 2008). However, should the United States eventually adopt wage-replacement benefits - as have some states - the prevailing norm of gender-neutral, individual entitlements may help to align U.S. federal family policy more closely with gender-egalitarian family policy models.

Third, leave provisions in the United States are distinguished by medical and caregiving needs, and many leave laws provide job-protected time-off to address either or both needs. In contrast, provisions in other countries can be distinguished by who provides care (i.e., mother, father/partner, relative) and who receives care (i.e., self, new child, older child, or relative) (see Blum, Koslowski, Macht, \& Moss, 2018; Daly \& Ferragina, 2018). For example, in other countries, maternity leave provides paid time-off for female employees during the late stages of pregnancy, for childbirth, and to care for/bond with a newborn, thus combining medical and caregiving needs and emphasizing ties between female bodies and caregiving (see Blum et al., 2018). In the United States, paternity leave, or time-off for fathers surrounding the birth of a child, does not exist as a distinct provision. Instead, fathers, when eligible, have rights under gender-neutral parental or-more commonly-family leave laws, and the duration of leave for fathers (and other non-birth parents) is the same as for (birth-)mothers. ${ }^{19}$ These laws, therefore, frame leave to care

\footnotetext{
${ }^{19}$ All current family leave laws cover care for adopted children and children of same-sex couples with legal guardianship. Coverage of same-sex spouses became universal across states when the U.S. Supreme Court overturned state-level same-sex marriage bans in 2015, though some states recognized same-sex marriage or extended leave rights to same-sex partners before the ruling. Some state laws additionally cover children of employees standing "in loco parentis" (i.e., individuals caring for a
} 
for and bond with a new child as meeting non-gendered needs. ${ }^{20}$ By distinguishing between medical and caregiving needs and defining pregnancy and childbirth as temporary disabilities among many types of disabilities, leave law in the United States emphasizes the need for leave as something any worker may experience.

Finally, U.S. leave laws often merge provisions to care for new children (parental leave) with provisions to care for older children or other family members (family or carers leave). Given that some states now provide wagereplacement benefits during family leave, some American workers have access to family/carers leave provisions that surpass other countries in terms of duration and benefits. For example, New York's paid family leave insurance program, which will be fully implemented in 2021, is among the most generous state insurance programs. The program covers up to 12 weeks of family caregiving leave paid at $67 \%$ of employees' earnings and capped at $67 \%$ of the statewide average weekly wage (see Engeman et al., 2019). Countries with annual provisions of paid family (or carers) leave offer two weeks of benefit payments at most (see OECD, 2014). ${ }^{21}$ Even unpaid family leave under the FMLA and state laws exceed carers' leave provisions in many other affluent countries. For example, carers' leave in Canada, Greece, and Portugal is unpaid and shorter in duration compared to the FMLA (see OECD, 2014).

\section{Has the Historical Moment for Paid Leave Passed?}

Countries and states that provide wage-replacement benefits during parental leave often started with a focus on mothers and an acknowledged role for the state in administering paid benefits (see Gauthier, 2004 [1996]). By the time Congress introduced the first version of the FMLA, paid maternity leave had been available in other countries for decades (ibid.). Some of these countries, starting in the 1990s, extended individual entitlements to paid leave

child regardless of legal guardianship), for example, grandparents with primary care responsibilities for grandchildren.

${ }^{20}$ Out of 72 enacted leave laws, only two-in Massachusetts and Vermont-restricted bonding leave to mothers. However, both states later reformed their laws to extend leave rights to fathers.

${ }^{21}$ Some countries offer more generous benefits than state-level programs in the United States Italy offers a two-year lifetime provision of family caregiving leave paid at $100 \%$ of previous earnings, and other countries offer "per episode" provisions of well-compensated leave (i.e., $60 \%$ or more of previous earnings), ranging from two days to one year (see OECD, 2014). Funding of eldercare services also varies across countries, which may inform the need for private, family care (Brandt, Haberkern, \& Szydlik, 2009) and therefore, support for family caregiving through paid leave entitlements or cash-for-care schemes (Bouget, Saraceno, \& Spasova, 2017). 
to fathers (see OECD, 2014)—around the time the United States adopted unpaid family and medical leave. Additionally, most states that now offer paid family leave insurance likewise started with a focus on mothers, providing paid leave benefits for pregnancy and childbirth through temporary disability insurance programs established prior to 1970.

By the time family policy entered the U.S. national legislative agenda in the 1980 s, a focus on mothers was no longer acceptable (see Elving, 1995; Shiu \& Wildman, 2009). By acting late on family policy, American lawmakers and leave proponents were restricted to favoring unpaid (gender-neutral) individual entitlements over paid (gendered) maternity leave, possibly limiting opportunities to adopt paid leave in subsequent decades. While other social policies and workplace protections in the United States have started with an appeal to women's special status as child-bearers and family caregivers (Skocpol, 1992), contemporary leave proponents are now in a challenging position to win new rights for workers without starting with a narrow-and historically compelling - appeal to protect mothers.

Yet, recent changes at the state level offer hope for paid parental and family leave expansions. In 2017, Washington established a paid family leave insurance program, making it the first state to do so without a preexisting funding mechanism (e.g., a state disability insurance program). Prior to Washington State, Washington, DC also passed a paid family leave law. Massachusetts, in 2018, adopted 12 weeks of paid parental and family leave and 20 weeks of paid medical leave covering pregnancy and childbirth. Employees can combine the leave for a total of 36 weeks. Lastly, in 2019, Oregon became the most recent state to adopt paid family leave insurance. Its program includes a $100 \%$ wage-replacement rate for its lowest earners (i.e., people earning $65 \%$ or less of the statewide average weekly wage) (NPWF, 2019).

How were these subnational governments able to do something others have not? Previous research suggests a combination of social movement pressure and allies in government motivate family policy reforms in U.S. states. Qualitative studies suggest that women's organizations (Bernstein, 2001; Sholar, 2016) and organized labor play leading roles in facilitating leave policy adoption (Milkman \& Appelbaum, 2013), and quantitative analysis shows that states with stronger trade union institutions are faster to adopt gender-neutral leave rights (Engeman, 2020). Democratic lawmakers and majorities in legislative offices are also important (Engeman, 2020; Milkman \& Appelbaum, 2013; Sholar, 2016). Drawing from the research presented in this chapter, Democratic majorities in the state legislature matter for the expansion of leave rights and provisions. Of the 26 state leave laws that passed 
since the FMLA, $22(85 \%)$ passed when Democrats held a majority of seats in both state houses, and Democratic governors signed 23 (88\%) of them.

Leave advocates can also expand leave rights and provisions by circumventing state legislatures. Three states created paid sick leave rights by using ballot initiatives that propose the policy directly to voters. Using ballot measures to establish state-level leave rights is a relatively recent tactic, with Massachusetts in 2014 as the first state to successfully adopt paid sick leave in this way. Counties and municipalities can also establish leave rights. As of 2016, twenty-nine municipalities had paid sick leave ordinances that cover workers within city limits (NPWF, 2016b). In another recent development, San Francisco and Washington, DC require employers to supplement benefits paid by the state/district family leave insurance programs (see Kaufman, 2019).

Ballot initiatives can also motivate reforms via traditional legislative channels. Massachusetts and Washington established paid family leave insurance programs following efforts to pass ballot initiatives. In Massachusetts, the ballot initiative would have provided up to 16 weeks of family leave paid through an employer-funded, state-administered program (Salsberg, 2017). In Washington, voters passed a ballot initiative backed by organized labor that increased the state minimum wage and required employers provide up to 40 hours of paid sick leave per year (Jenkins, 2017). In both states, some business leaders and other usual opponents to leave legislation supported the state bills, because they thought a ballot initiative would pass and they would have more control over the content of legislation using the state legislative process (see Jenkins, 2017; Salsberg, 2018). With ballot initiatives, voters decide whether to pass legislation as written by proponents. With the state legislative process, however, opponents can propose amendments, for example, introducing restrictive eligibility requirements, shortening duration, or lowering benefit levels. Thus, introducing or threatening to introduce ballot initiatives may reduce opposition to reforms and offer another tactic for facilitating state action.

Establishing paid leave provisions or other improvements to leave access is unlikely at the federal level in the near future. While most Americans want access to paid leave, they agree less about how this should happen (Horowitz, Parker, Graf, \& Livingston, 2017). In order to establish paid leave provisions at the federal level, research on state policy development suggests a need for Democrats to control the legislative branch of government (Engeman, 2020). Even with this control, however, Congress would need to prioritize paid family and medical leave above other-arguably more pressing-social issues, such as improving the healthcare system, funding social security, or 
addressing climate change, among others. Until that time, states with leavefavorable political conditions will likely be the site of family policy innovation in the United States.

\section{Conclusions}

Examining cross-state variation in U.S. leave policy, this chapter discusses 72 leave laws adopted by states between 1942 and 2017. This chapter thus makes several contributions. First, I identify seven main types of state leave policy and argue that these policies can be distinguished by whether the leave addresses either medical or caregiving needs, which is in contrast to leave policies in other countries that can be distinguished by who provides and who receives care. Thus, unlike leave provisions in other countries, an employee's sex or gender does not determine leave entitlements under most state or federal laws (or any laws adopted after 1993). Accordingly, leave for pregnancy and childbirth fits within a gender-neutral need to address a temporary disability, and leave to bond with a child is a separate, genderneutral, individual entitlement. Second, an increasing number of states are creating paid leave insurance programs, and the more active states are more generous, suggesting efficacy for incremental reforms in some states. Third, for leave to care for non-child relatives (i.e., family or carers leave), I argue that provisions in some states approach or exceed provisions in other affluent countries where carers' leave is a more recent development (see Bouget et al., 2017). Finally, I point to the prevalence of gender-neutral individual entitlements to job-protected leave to suggest potential for U.S. family policy to catch up to family policies in other affluent countries. Leave proponents can and have layered wage-replacement benefits on top of already-existing, gender-neutral individual entitlements. As states take this layering approach to create family leave insurance programs, they establish provisions that are more comparable to gender-egalitarian family models in other countries.

Cross-national comparative analysis of family policy should be attentive to subnational policy developments in the United States for at least three reasons. First, cross-national comparative studies that include the United States in analysis must be careful in treating the United States as a country that lacks leave rights entirely. The six states that had paid family leave insurance programs as of 2017 are-aside from Rhode Island—among the nation's most populous. In 2018, workers in these states constituted over one-fourth (26\%) of the U.S. workforce (U.S. Bureau of Labor Statistics, 2018). While some workers in these states may not meet eligibility requirements for leave, 
a sizeable and growing proportion of the workforce has access to paid leave provisions under state laws with others possibly covered by employers or collective bargaining agreements. Future cross-national comparative analysis could exclude data from states with paid leave insurance or examine these states separately.

Second, subnational family policy variation offers a rich area for future research. In the following Chapter 18 (in this volume), Zachary Parolin and Rosa Daiger von Gleichen examine the implications of a broad set of family policies for poverty rates, household expenditures, and gender equality in the labor market. Though they find little evidence that state-level policy variation results in a variation in outcomes, recent increases in leave benefit levels under existing state programs and the introduction of new insurance programs in more states, warrant a return to this question of subnational policy variation and outcomes in the future. Additionally, cross-national studies of parental and family leave policy outcomes could potentially include some states in analysis. For example, California, the world's fifth largest economy (Associated Press, 2018), would offer an interesting comparative case, given that its paid leave program has been in effect since 2004. Future research could also examine relationships between family/carers leave provisions and women's labor force participation and earnings at later career stages.

Finally, state-level legislative action may eventually influence federal policy. Researchers have noted the potential for policy diffusion across states and different levels of government (e.g., see Chapter 4 by White in this volume). The FAMILY Act, currently introduced in the House (HR 1185), would establish an insurance program to pay benefits during medical, parental, and family caregiving leave, similar to legislation adopted by states. Benefits would be paid as gender-neutral, individual entitlements. As with other social policies in the United States, states can serve as laboratories where new policy ideas are tested before they spread (see Volden, 2006), and states are the likely sites for leave policy innovation as well.

Acknowledgements Preparation of this manuscript was supported by the European Commission, Marie Skłodowska-Curie Actions (742339-ERA).

\section{References}

Associated Press. (2018, May 4). California is now the world's fifth-largest economy, surpassing United Kingdom. Los Angeles Times. 
Bernstein, A. (2001). The moderation dilemma: Legislative coalitions and the politics of family and medical leave. Pittsburgh, PA: University of Pittsburgh Press.

Blum, S., Koslowski, A., Macht, A., \& Moss, P. (2018). International review of leave policies and research 2018. Available at: http://www.leavenetwork.org/lp_and_r_r eports/.

Borchorst, A. (2006). The public-private split rearticulated: Abolishment of the Danish daddy leave. In A. L. Ellingsæter \& A. Leira (Eds.), Politicizing parenthood: Gender relations in a Scandinavian welfare state design (pp. 101-120). London: The Polity Press.

Bouget, D., Saraceno, C., \& Spasova, S. (2017). Towards new work-life balance policies for those caring for dependent relatives? Social Policy in the European Union: State of Play.

Brandt, M., Haberkern, K., \& Szydlik, M. (2009). Intergenerational help and care in Europe. European Sociological Review, 25(5), 585-601.

Brandth, B., \& Kvande, E. (2018). Enabling or promoting gender equality though parental leave policies. Revista Española de Sociología, 27(3), 107-120.

Chronholm, A. (2009). Sweden: Individualisation or free choice in parental leave? In S. Kamerman \& P. Moss (Eds.), The politics of parental leave policies: Children, parenting and the labour market (pp. 227-243). Bristol: Policy Press.

Cukrowska-Torzewska, E. (2017). Cross-country evidence on motherhood employment and wage gaps: The role of work-family policies and their interaction. Social Politics, 24(2), 178-220.

Daly, M. (2010). Shifts in family policy in the UK under new labour. Journal of European Social Policy, 20(5), 433-443.

Daly, M., \& Ferragina, E. (2018). Family policy in high-income countries: Five decades of development. Journal of European Social Policy, 28(3), 255-270.

Duvander, A.-Z., \& Johansson, M. (2012). What are the effects of reforms promoting fathers' parental leave use? Journal of European Social Policy, 22(3), 319-330.

Ellingsæter, A. L. (2012). Ideational struggles over symmetrical parenthood: The Norwegian daddy quota. Journal of Social Policy, 41, 695-714.

Elving, R. D. (1995). Conflict and compromise: How congress makes the law. New York, NY: Simon \& Schuster.

Engeman, C. (2016). Family values at work: Social movements and the politics of leave legislation in the U.S. Santa Barbara: University of California, Santa Barbara.

Engeman, C. (2018). Time for care: A history of state leave legislation in the United States (Swedish Institute for Social Research (SOFI) Stockholm University Working Paper 9/2018).

Engeman, C. (2020). When do unions matter to social policy? Organized labor and leave legislation in US states. Social Forces, 1-27. https://doi.org/10.1093/sf/soa a074.

Engeman, C., Petts, R. J., Gatenio Gabel, S., \& Kaufman, G. (2019). United States country note. In A. Koslowski, S. Blum, I. Dobrotić, A. Macht, \& P. Moss (Eds.), 
International review of leave policies and research 2019. Available at: http://www. leavenetwork.org/lp_and_r_reports/.

Escot, L., Fernádez-Cornejo, J. A., \& Poza, C. (2014). Fathers' use of childbirth leave in Spain: The effects of the 13-day paternity leave. Population Research and Policy Review, 33(3), 419-453.

Eydal, G. B., Gíslason, I. V., Rostgaard, T., Brandth, B., Duvander, A.-Z., \& Lammi-Taskula, J. (2015). Trends in parental leave in the Nordic countries: Has the forward march of gender equality halted? Community, Work \& Family, 18(2), $167-181$.

Firestein, N., O’Leary, A., \& Savitsky, Z. (2011). A guide to implementing paid family leave: Lessons from California. Berkeley, CA: Berkeley Center on Health, Economic \& Family Security, UC Berkeley School of Law. Available at: www. law.berkeley.edu/chefs.htm.

Gauthier, A. H. (2004 [1996]). The state and the family: A comparative analysis of family policies in industrialized countries. Oxford: Oxford University Press.

Gornick, J. C., \& Meyers, M. K. (2008). Creating gender egalitarian societies: An agenda for reform. Politics \& Society, 36 (3), 313-349.

Gould, E., Filion, K., \& Green, A. (2011). The need for paid sick days: The lack of a federal policy further erodes family economic security. Washington, DC: Economic Policy Institute.

Greenhouse, S. (2009, November 2). Lack of paid sick days may Worsen Flu pandemic. New York Times.

Haas, L., \& Rostgaard, T. (2011). Fathers' rights to paid parental leave in the Nordic countries: Consequences for the gendered division of leave. Community, Work \& Family, 14(2), 177-195.

Heymann, J., Earle, A., \& Hayes, J. (2007). The work, family, and equity index: How does the United States measure up? Montreal: The Project on Global Working Families.

Horowitz, J. M., Parker, K., Graf, N., \& Livingston, G. (2017, March 23). Americans widely support paid family and medical leave, but differ over specific policies. Washington, DC: Pew Research Center. Available at: https://www.pewsocialtrends.org/2017/03/23/americans-widely-support-paidfamily-and-medical-leave-but-differ-over-specific-policies/.

Jenkins, A. (2017, July 5). Washington workers will get paid family, medical leave benefits beginning in 2020. KNKX.

Karu, M., \& Tremblay, D.-G. (2017). Fathers on parental leave: An analysis of rights and take-up in 29 countries. Community, Work \& Family, 21(3), 344-362.

Kaufman, G. (2018). Barriers to equality: Why British fathers do not use parental leave. Community, Work \& Family, 21(3), 310-325.

Kaufman, G. (2019). United States: Leave policy, failure and potential. In P. Moss, A.-Z. Duvander, \& A. Koslowski (Eds.), Parental leave and beyond: Recent international developments, current issues and future directions. Bristol: Policy Press.

Klerman, J. A., Daley, K., \& Pozniak, A. (2014). Family and medical leave in 2012: Technical report. Cambridge, MA: Abt Associates. 
Korpi, W., Ferrarini, T., \& Englund, S. (2013). Women's opportunities under different family policy constellations: Gender, class, and inequality tradeoffs in Western counties re-examined. Social Politics, 20(1), 1-40.

Koslowski, A., Blum, S., Dobrotić, I., Macht, A., \& Moss, O. (2019). International review of leave policies and research 2019. Available at: https://www.leavenetwork. org/annual-review-reports/.

Maldonado, L. C., \& Nieuwenhuis, R. (2015). Family policies and single parent poverty in 18 OECD countries, 1978-2008. Community, Work \& Family, 18(4), 395-415.

Milkman, R., \& Appelbaum, E. (2013). Unfinished business: Paid family leave in California and the future of U.S. work-family policy. Ithaca, NY: ILR Press.

Moss, P. (2008). Making parental leave parental. In P. Moss \& K. Korintus (Eds.), International review of leave policies and research (pp. 44-62). Employment Relations Series No. 100. London: Department of Business Enterprise and Regulatory Reform.

National Conference of State Legislatures (NCSL). (2008). State family and medical leave laws that differ from the federal FMLA. Washington, DC: NCSL. http://ncsl. org/print/employ/fam-medleave.pdf. Accessed 22 Aug 2018.

National Partnership for Women and Families (NPWF). (2015a). Existing temporary disability insurance programs. Washington, DC: NPWF. Available at: http://www.nationalpartnership.org/research-library/work-family/paidleave/existing-tdi-programs.pdf.

National Partnership for Women and Families (NPWF). (2015b). State and local action on paid sick days. Washington, DC: NPWF. Available at: http://www.nat ionalpartnership.org/research-library/campaigns/psd/state-and-local-action-paidsick-days.pdf.

National Partnership for Women and Families (NPWF). (2016a). Expecting better: $A$ state-by-state analysis of laws that help expecting and new parents. Washington, DC: NPWF. Available at: http://www.nationalpartnership.org/research-library/workfamily/expecting-better-2016.pdf.

National Partnership for Women and Families (NPWF). (2016b). Current paid sick days laws. Washington, DC: National Partnership for Women and Families.

National Partnership for Women and Families (NPWF). (2017a). State paid family leave insurance laws. Washington, DC: NPWF. Available at: http://www.nationalpartnership.org/research-library/work-family/paid-leave/ state-paid-family-leave-laws.pdf.

National Partnership for Women and Families (NPWF). (2017b). Reasonable accommodations for pregnant workers: State and local laws. Washington, DC: NPWF. Available at: http:/www.nationalpartnership.org/our-work/resources/ workplace/pregnancy-discrimination/reasonable-accommodations-for-pregnantworkers-state-laws.pdf.

National Partnership for Women and Families (NPWF). (2018). Paid sick daysState and district statutes. Washington, DC: NPWF. Available at: http://www. nationalpartnership.org/research-library/work-family/psd/paid-sick-days-statutes. pdf. 
National Partnership for Women and Families (NPWF). (2019). State paid family and medical leave laws, August 2019. Washington, DC: NPWF. Available at: http://www.nationalpartnership.org/research-library/work-family/paidleave/state-paid-family-leave-laws.pdf.

OECD. (2014). PF2.3: Additional leave entitlements for working parents. OECD Family Policy Database. https://www.oecd.org/els/soc/PF2_3_Additional_leave_ entitlements_of_working_parents.pdf. Accessed 29 June 2016.

Pavalko, E. K., \& Henderson, K. A. (2006). Combining care work and paid work: Do workplace policies make a difference? Research on Aging, 28(3), 359-374.

Rønsen, M., \& Sundström, M. (2002). Family policy and after-birth employment among new mothers-A comparison of Finland, Norway and Sweden. European Journal of Population, 18(2), 121-152.

Rosenfeld, P. (2007). Workplace practices for retaining older hospital nurses: Implications from a study of nurses with eldercare responsibilities. Policy, Politics \& Nursing Practice, 8(2), 120-129.

Rossin, M. (2011). The effects of maternity leave on children's birth and infant health outcomes in the United States. Journal of Health Economics, 30(2), 221239.

Rossin-Slater, M., Ruhm, C. J., \& Waldfogel, J. (2013). The effects of California's paid family leave program on mothers' leave-taking and subsequent labor market outcomes. Journal of Policy Analysis and Management, 32(2), 224-245.

Ruhm, C. J. (2000). Parental leave and child health. Journal of Health Economics, 19(6), 931-960.

Ruppanner, L. (2013). Conflict between work and family: An investigation of four policy measures. Social Indicators Research, 110(1), 327-347.

Salsberg, B. (2017, July 31). \$15 minimum wage and paid leave questions proposed for 2018 Mass. Ballot. WBUR.

Salsberg, B. (2018, June 20). Mass. Legislators strike deal with bill on family leave, sales tax holiday and \$15 minimum wage. WBUR.

Shiu, P. A., \& Wildman, S. M. (2009). Pregnancy discrimination and social change evolving consciousness about a worker's right to job-protected, paid leave. Yale Journal of Law \& Feminism, 21(1), 119-159.

Sholar, M. A. (2016). Getting paid while taking time: The women's movement and the development of paid family leave policies in the United States. Philadelphia: Temple University Press.

Skocpol, T. (1992). Protecting soldiers and mothers: The political origins of social policy in the United States. Cambridge: Harvard University Press.

U.S. Bureau of Labor Statistics. (2018). Employment status of the civilian population by sex, race, Hispanic or Latino ethnicity, and intermediate age, 2018 annual averages. Washington, DC: U.S. Bureau of Labor Statistics. https://www.bls.gov/lau/ table14afull18.pdf. Accessed 19 Aug 2020.

U.S. Department of Labor. (2015). Employment protections for workers who are pregnant or nursing. Washington, DC: U.S. Department of Labor. http://www.dol. gov/wb/maps/. Accessed 23 Mar 2015. 
Volden, C. (2006). States as policy laboratories: Emulating success in the children's health insurance program. American Journal of Political Science, 50(2), 294-312.

Waldfogel, J. (2001). Family and medical leave: Evidence from the 2000 surveys. Monthly Labor Review, 124(9), 17-23.

Widera, E., Chang, A., \& Chen, H. L. (2010). Presenteeism: A public health hazard. Journal of General Internal Medicine, 25(11), 1244-1247.

Williamson, S., \& Carnes, M. (2013). Partisanship, Christianity, and women in the legislature: Determinants of parental leave policy in U.S. states. Social Science Quarterly, 94(4), 1084-1101.

Wisensale, S. K., \& Allison, M. D. (1989). Family leave legislation: State and federal initiatives. Family Relations, 38(2), 182-189.

Women's Bureau. (1993). State maternity/family leave law. Washington, DC: U.S. Department of Labor.

Women's Bureau. (2017). Employment protections for workers who are pregnant or nursing. Washington, DC: U.S. Department of Labor. http://www.dol.gov/wb/ maps. Accessed 22 Aug 2018.

Workplace Flexibility. (2010). Georgetown University Law Center and Berkeley Center on Health, Economic \& Family Security, UC Berkeley School of Law. Family Security Insurance: A New Foundation for Economic Security. Published Reports 3. Available at: https://scholarship.law.georgetown.edu/pub_rep/3.

Open Access This chapter is licensed under the terms of the Creative Commons Attribution 4.0 International License (http://creativecommons.org/licenses/by/4.0/), which permits use, sharing, adaptation, distribution and reproduction in any medium or format, as long as you give appropriate credit to the original author(s) and the source, provide a link to the Creative Commons licence and indicate if changes were made.

The images or other third party material in this chapter are included in the chapter's Creative Commons licence, unless indicated otherwise in a credit line to the material. If material is not included in the chapter's Creative Commons licence and your intended use is not permitted by statutory regulation or exceeds the permitted use, you will need to obtain permission directly from the copyright holder. 